\title{
Assessing accuracy of gas-driven permeability measurements: a comparative study of diverse Hassler-cell and probe permeameter devices
}

\author{
C. M. Filomena ${ }^{1}{ }^{*}$, J. Hornung ${ }^{2}$, and H. Stollhofen ${ }^{1}$ \\ ${ }^{1}$ GeoZentrum Nordbayern, Friedrich-Alexander-Universität Erlangen-Nürnberg, Erlangen, Germany \\ ${ }^{2}$ Institut für Angewandte Geowissenschaften, Technische Universität Darmstadt, Darmstadt, Germany \\ *current address: Shell Global Solutions B.V., Rijswijk, the Netherlands \\ Correspondence to: C. M. Filomena (claudio.filomena@shell.com)
}

Received: 1 July 2013 - Published in Solid Earth Discuss.: 2 August 2013

Revised: 26 November 2013 - Accepted: 27 November 2013 - Published: 2 January 2014

\begin{abstract}
Permeability is one of the most important petrophysical parameters to describe the reservoir properties of sedimentary rocks, pertaining to problems in hydrology, geothermics, and hydrocarbon reservoir analysis. Outcrop analogue studies, well core measurements, and individual sample analysis take advantage of a variety of commercially available devices for permeability measurements. Very often, permeability data derived from different devices need to be merged within one study (e.g. outcrop minipermeametry and lab-based core plug measurements). To enhance accuracy of different gas-driven permeability measurements, devicespecific aberrations need to be taken into account. The application of simple one-to-one correlations may draw the wrong picture of permeability trends. For this purpose, transform equations need to be established.

This study presents a detailed comparison of permeability data derived from a selection of commonly used Hassler cells and probe permeameters. As a result of individual crossplots, typical aberrations and transform equations are elaborated, which enable corrections for the specific permeameters. Permeability measurements of the commercially available ErgoTech gas permeameter and the TinyPerm II probe permeameter are well-comparable over the entire range of permeability, with $R^{2}=0.955$. Aberrations are mostly identified in the permeability range $<10 \mathrm{mD}$, regarding the TinyPerm II and the minipermeameter/Hassler-cell combination at Darmstadt University, which need to be corrected and standardized. Applying standardizations which consider these aberration intervals strongly improves the comparabil-
\end{abstract}

ity of permeability data sets and facilitates the combination of measurement principles. Therefore, the utilization of such correlation tests is highly recommended for all kinds of reservoir studies using integrated permeability databases.

\section{Introduction}

Petrophysical properties of sedimentary rocks are decisive parameters for the quantitative and qualitative evaluation of reservoir rocks. One of the most important measurement values is permeability, describing the magnitude of fluid flow through porous media. Reliable permeability values are a prerequisite for the assessment and modelling of hydrocarbon, carbon dioxide capture and storage, and geothermal reservoir rocks (Li et al., 1995; Branets et al., 2009; Dezayes et al., 2007; Grant and Bixley, 2011; Hurst, 1993; Laughlin, 1982) and their economic and sustainable production (Davies and Davies, 2001; Dutton et al., 1991). They are also crucial for hydrological studies (Huysmans et al., 2008; Todd and Mays, 2005; Al Ajmi et al., 2013) and underground waste disposal, including modelling of fluid flow and potential contaminant spread.

Laboratory-based permeability measurements are commonly performed on core plug samples from well core material. Gas-driven permeability measurements have the advantage of being quickly performed. They do not contaminate the sample, and they do not affect for example clay-bearing samples, which in the case of a fluid might swell and destroy 
the sample. A standard laboratory device for gas-driven permeability measurements is a Hassler cell (e.g. Thomas, 1972), allowing permeability measurements of entire core plug samples under steady-state gas flow. However, the resolution of permeability values measured (e.g. in a well core section) strongly depends on the plug core sampling rate (Goggin, 1993).

During the last decades, non-destructive and cost-efficient minipermeametry (or probe permeametry) has become an important analytic tool, providing fast and highly resolving permeability data for both laboratory and in situ outcrop applications (Davis et al., 1994; Sharp Jr. et al., 1994; Goggin, 1988; Dutton and Willis, 1998; Goggin, 1993; Dreyer et al., 1990; Chandler et al., 1989; Hornung and Aigner, 2002; Fossen et al., 2011; Rogiers et al., 2011; Iversen et al., 2003; Eijpe and Weber, 1971; Huysmans et al., 2008). Most probe permeameters apply a steady-state or unsteadystate gas injection (e.g. Hurst and Goggin, 1995) with gas flowing from the probe tip through the sample rock volume. However, some devices also apply a vacuum, where the gas flows into the probe. Automated laboratory probe permeametry is commonly applied to core slab surfaces oriented perpendicular to sedimentary bedding, referred to as bedding-parallel permeability (Corbett and Jensen, 1992; Robertson and McPhee, 1990). The resulting permeability maps are further enrolled in rock property analysis and reservoir characterization (Halvorsen and Hurst, 1990; Robertson and McPhee, 1990; Willis, 1998). Minipermeametry has the potential to resolve bedding-, deformation- and diagenesisdependent permeability heterogeneities in stratified sedimentary rocks at centimetre-scale (e.g. Huysmans et al., 2008). However, minipermeameter and Hassler-cell-derived permeability data are not directly comparable with one another. Meyer and Krause (2001) document almost constantly higher probe-derived permeability values than those from Hassler cell measurements. TinyPerm-derived permeabilities obtained from the the highly permeable Navajo Sandstone were found to be 1.8 times higher than plug-derived permeability values (Fossen et al., 2011; Torabi and Fossen, 2009). Sutherland et al. (1993) discuss not only the advantages but also limitations of probe permeametry, emphasizing the need of standardized experimental conditions.

The combination of permeability data obtained from different approaches (e.g. from a probe permeameter and a Hassler cell) within one study therefore needs to be treated with caution. Here, it is of crucial importance to be aware of the scaling of rock heterogeneities and possible discrepancies between the measuring results. In this study, four air-driven permeameters are tested for comparability among each other. In order to assess the accuracy of different Hassler cell and miniperm devices, similarities as well as potential discrepancies are evaluated. Ultimately, research studies integrating different permeameter devices (e.g. for field and laboratory analysis) shall benefit from a much higher accuracy by ap- plying transfer functions for a standardization of permeameter measurements.

\section{Samples, methods, and specifications}

\subsection{Sample material}

For this study we used 51 cylindrical and bedding-parallel sandstone sample plugs of a standardized 1-inch $(2.54 \mathrm{~cm})$ diameter and $5 \mathrm{~cm}$ length. Prior to permeability measurements the sample plugs were oven-dried at $60^{\circ} \mathrm{C}$ for 3 days, until a constant weight was reached. Permeability measurements were performed along the long axis of the core plugs to exclude orientation-related anisotropy effects. The data set presented here (Table 1) covers a permeability range over six orders of magnitude, from $10^{-2}$ to $10^{3} \mathrm{mD}$. Samples with low and moderate permeabilities of 0.02 to $300 \mathrm{mD}$ are derived from fluvial channel sandstones of the Triassic Buntsandstein (sample numbers 1-13 and 43-48) and Keuper (sample numbers 14-38) of southern Germany. Highly permeable samples $(600$ to $>2700 \mathrm{mD}$ ) have been selected from two reservoir rocks: the Lower Cretaceous shallow marine Bentheim sandstone (sample numbers 40-42), which forms the host rock of a hydrocarbon reservoir in northwest Germany and the Netherlands (cf. Roll, 1972); and the Late Ordovician shallow marine Dibsiyah Formation (sample number 39) of the Wajid Group in the Kingdom of Saudi Arabia (Kellogg et al., 1986; Al Ajmi et al., 2013), which is part of a regional mega-aquifer system (GTZ-DCO, 2007). The three Buntsandstein samples 49-51 also exhibit high permeabilities of $800-1800 \mathrm{mD}$.

To provide an almost homogeneous sample material, only very well to well-sorted, fine- to medium-grained, massive sandstones were selected. Quartz is the dominant grain type with rounded to subrounded grains, followed by minor amounts of feldspar $(<15 \%)$. Some low-permeability $\left(10^{-2}-10^{1} \mathrm{mD}\right)$ Buntsandstein samples additionally contain $1-6 \%$ illite, and quartz and carbonate occur as cementing phases. The Keuper samples are mainly kaolinite-cemented, with a minor amount of carbonate cements. They mostly plot within the $10^{1} \mathrm{mD}$ permeability range. The remaining samples with permeabilities of $>10^{2} \mathrm{mD}$ are essentially clayfree and are quartz- or carbonate-cemented (Bentheim sandstone, Dibsiyah Formation, and some Buntsandstein samples). However, it should be stated at this point that the presented samples of the different formations/stratigraphies do not represent the full permeability range of the respective formation. In general, the samples have systematically been selected, independent of their stratigraphic position or origin, to cover a vast range of permeability magnitudes and to compare the different permeameter types properly. 
Table 1. Permeability data set of 51 sandstone sample plugs, measured with four different devices: the Hassler cells of the ErgoTech gas permeameter (HET) and the gas permeameter in Darmstadt (HDA), and the minipermeameters New England Research TinyPerm II (MTP) and Miniperm Darmstadt (MDA). According to Table 2, MTP permeabilities have additionally been corrected for unconfined sample geometries (MTP-c). Permeability values are given in $\mathrm{mD}$.

\begin{tabular}{|c|c|c|c|c|c|c|}
\hline HET & HDA & MDA & MTP & MTP-c & Plug no. & Stratigraphy \\
\hline 0.07 & 0.10 & 10.29 & 0.10 & 0.06 & 48 & Buntsandstein \\
\hline 0.17 & 0.10 & 0.62 & 0.39 & 0.25 & 47 & Buntsandstein \\
\hline 0.32 & 0.35 & 0.43 & 0.26 & 0.16 & 1 & Buntsandstein \\
\hline 0.48 & 0.40 & 0.42 & 0.37 & 0.23 & 4 & Buntsandstein \\
\hline 0.52 & 0.60 & 1.53 & 1.20 & 0.76 & 46 & Buntsandstein \\
\hline 0.77 & 0.80 & 3.60 & 1.72 & 1.09 & 44 & Buntsandstein \\
\hline 0.97 & 0.90 & 3.36 & 8.73 & 5.51 & 24 & Keuper \\
\hline 1.57 & 0.28 & 5.16 & 2.05 & 1.29 & 32 & Keuper \\
\hline 1.73 & 1.00 & 1.56 & 1.26 & 0.80 & 45 & Buntsandstein \\
\hline 1.75 & 1.36 & 3.45 & 1.88 & 1.19 & 3 & Buntsandstein \\
\hline 1.78 & 0.60 & 4.46 & 3.09 & 1.95 & 25 & Keuper \\
\hline 2.07 & 2.07 & 2.38 & 1.89 & 1.19 & 2 & Buntsandstein \\
\hline 2.43 & 1.90 & 3.60 & 3.02 & 1.91 & 43 & Buntsandstein \\
\hline 3.45 & 0.10 & 4.71 & 1.32 & 0.83 & 15 & Keuper \\
\hline 4.23 & 2.45 & 5.80 & 4.74 & 2.99 & 23 & Keuper \\
\hline 5.00 & 0.80 & 6.06 & 6.05 & 3.82 & 14 & Keuper \\
\hline 7.19 & 3.40 & 9.08 & 5.86 & 3.70 & 19 & Keuper \\
\hline 7.35 & 6.10 & 3.04 & 2.22 & 1.40 & 11 & Buntsandstein \\
\hline 9.65 & 9.53 & 11.95 & 5.72 & 3.61 & 17 & Keuper \\
\hline 10.75 & 3.20 & 12.86 & 13.25 & 8.36 & 16 & Keuper \\
\hline 11.36 & 1.80 & 13.85 & 11.11 & 7.01 & 18 & Keuper \\
\hline 11.88 & 11.39 & 14.64 & 10.75 & 6.78 & 33 & Keuper \\
\hline 18.53 & 18.10 & 22.32 & 20.52 & 12.95 & 10 & Buntsandstein \\
\hline 20.79 & 28.60 & 22.99 & 13.93 & 8.79 & 13 & Buntsandstein \\
\hline 27.94 & 27.50 & 29.64 & 23.41 & 14.77 & 7 & Buntsandstein \\
\hline 42.30 & 40.30 & 50.17 & 36.78 & 23.21 & 6 & Buntsandstein \\
\hline 44.08 & 37.80 & 34.13 & 74.04 & 46.72 & 20 & Keuper \\
\hline 46.07 & 49.50 & 39.38 & 30.64 & 19.33 & 12 & Buntsandstein \\
\hline 49.72 & 67.00 & 52.17 & 120.42 & 75.99 & 37 & Keuper \\
\hline 54.25 & 47.10 & 48.15 & 81.65 & 51.52 & 22 & Keuper \\
\hline 56.00 & 53.30 & 44.86 & 88.47 & 55.82 & 34 & Keuper \\
\hline 56.50 & 60.10 & 45.48 & 63.56 & 40.11 & 5 & Buntsandstein \\
\hline 62.86 & 63.10 & 55.29 & 160.48 & 101.26 & 27 & Keuper \\
\hline 63.07 & 58.30 & 54.69 & 115.10 & 72.63 & 26 & Keuper \\
\hline 67.30 & 65.00 & 61.71 & 134.95 & 85.15 & 21 & Keuper \\
\hline 71.62 & 73.30 & 62.55 & 118.56 & 74.81 & 28 & Keuper \\
\hline 85.29 & 90.80 & 74.96 & 181.58 & 114.58 & 36 & Keuper \\
\hline 88.89 & 96.30 & 53.10 & 185.95 & 117.33 & 30 & Keuper \\
\hline 89.94 & 101.10 & 70.12 & 138.79 & 87.58 & 31 & Keuper \\
\hline 95.96 & 104.00 & 77.00 & 203.47 & 128.39 & 38 & Keuper \\
\hline 101.82 & 107.70 & 91.13 & 196.39 & 123.92 & 29 & Keuper \\
\hline 111.70 & 124.50 & 62.60 & 176.83 & 111.58 & 35 & Keuper \\
\hline 115.78 & 114.80 & 97.19 & 145.03 & 91.51 & 8 & Buntsandstein \\
\hline 214.08 & 148.20 & 72.74 & 173.08 & 109.21 & 9 & Buntsandstein \\
\hline 597.35 & 680.00 & 808.84 & 445.57 & 281.15 & 39 & Dibsiyah Fm. \\
\hline 859.91 & 980.10 & 403.92 & 678.75 & 428.29 & 51 & Buntsandstein \\
\hline 925.76 & 151.60 & 487.99 & 812.27 & 512.54 & 49 & Buntsandstein \\
\hline 1759.82 & 1766.20 & 1113.45 & 1441.14 & 909.36 & 50 & Buntsandstein \\
\hline 2167.00 & 2256.90 & 1899.75 & 2772.34 & 1749.35 & 42 & Bentheim sandstone \\
\hline 2217.45 & 2370.10 & 2857.35 & 4020.81 & 2537.13 & 41 & Bentheim sandstone \\
\hline 2722.26 & 2685.40 & 2250.72 & 4561.96 & 2878.60 & 40 & Bentheim sandstone \\
\hline
\end{tabular}




\subsection{Methods and devices}

Four gas-driven permeameter devices using three different concepts for permeability determination have been compared within this study:

(I) two Hassler cells (Fig. 1a),

(II) a minipermeameter (or probe permeameter) using air injection (Fig. 1b),

(III) a vacuum probe permeameter (Fig. 1c).

\subsubsection{Hassler cells}

Darcy's law describes the horizontal, laminar flow of a fluid under steady-state conditions in porous media with the known length and area of the sample. The permeability $(K)$ according to Darcy's law (Darcy, 1856) is given by

$K=Q \eta L / A \Delta P$,

with

- $K$ : permeability of the medium in $\mathrm{m}^{2}$ or $\mathrm{mD}$, $1 \mathrm{mD}=9.86923 \times 10^{-16} \mathrm{~m}^{2}$,

- $Q$ : flow rate, discharge volume per second in $\mathrm{m}^{2} \mathrm{~s}^{-1}$,

- $\eta$ : viscosity of the fluid in $\mathrm{Pa} \times \mathrm{s}$,

- $L$ : length of the sample in $\mathrm{m}$,

- A: the cross-sectional area of the sample in $\mathrm{m}^{2}$,

- $\Delta P$ : pressure difference between injection and outflow in $\mathrm{Pa}$.

Gas slippage at low pressures or high-velocity flow effects, such as turbulence, however, are neglected by this equation. Devices facilitating different pressure stages allow the Klinkenberg correction (Klinkenberg, 1941) and determination of an intrinsic permeability. A minimum of three (better five) subsequent measurements at equal flow rates but at different back-pressure steps and resulting differential pressures can be performed with Hassler cell devices. They are designed for uni-variant sample geometries, allowing a variable core plug length but demanding a constant sample diameter. Permeability measurements can only be applied in the long-axis direction of the sample plug. Therefore, the sample orientation is of basic importance, especially in heterogeneous rocks, where reservoir qualities are constrained by those sections with the lowest permeability.

The ErgoTech digital steady-state gas permeameter (Hassler-cell Ergo Tech = HET) at the Geological Institute of RWTH Aachen University is a laboratory-based instrument with an attached quick-action Hassler cell, hosting standard rock plugs of 1-inch $(2.54 \mathrm{~cm})$ diameter and a length of $7.6 \mathrm{~cm}$ maximum. The sample is sealed by a rubber sleeve

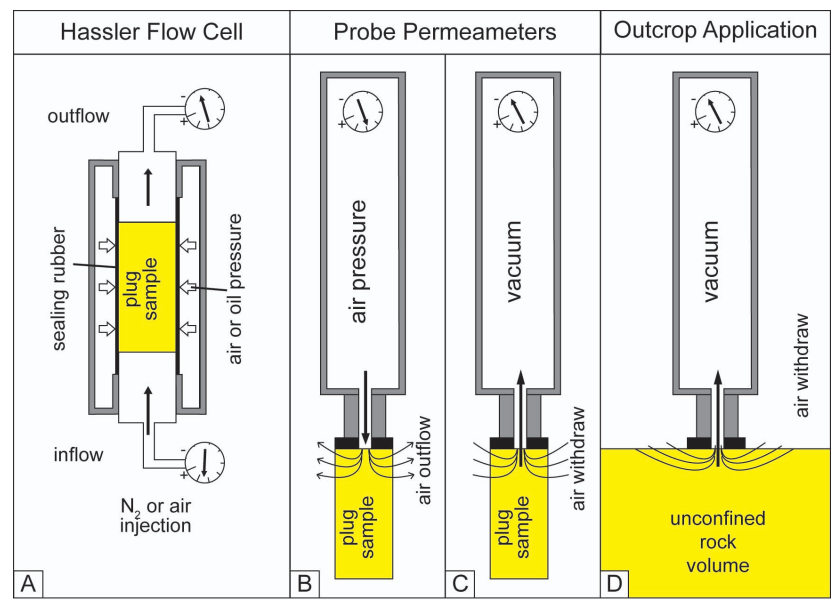

Fig. 1. Principles of permeability measurements on plug samples: (A) Hassler cell, (B) minipermeameter using air injection, and (C) minipermeameter applying a vacuum. Note the difference in rock volume and flow trajectories in (A), (B), (C). Likewise, the difference in rock volume needs to be taken into account when conducting outcrop measurements $=$ unconfined rock volume (D).

under a confining oil pressure of 50 bar. The operating gas temperature is measured with $0.1{ }^{\circ} \mathrm{C}$ accuracy. The HET is equipped with three mass flow meters of 20,200, and $2000 \mathrm{~cm}^{3} \mathrm{~min}^{-1}$ maximum. The applied back-pressure steps in the HET comprise measurement against atmospheric pressure, $20,25,30$, and $35 \mathrm{psi}$, resulting in a measuring range of $0.01 \mathrm{mD}$ to $10 \mathrm{D}$.

The gas permeameter at the Institute of Applied Geology at the Technical University of Darmstadt combines a Hassler cell $($ Hassler-cell Darmstadt $=$ HDA $)$ with a minipermeameter (MDA) in one device. The HDA can be operated with Hassler cells of different diameters at a sealing air pressure of $10 \mathrm{bar}$ and with freely selectable back-pressure steps up to 6 bar. Flow rates are sensitive from $0.001 \mathrm{~cm}^{3} \mathrm{~min}^{-1}$ up to $2000 \mathrm{~cm}^{3} \mathrm{~min}^{-1}$, allowing the measurement of a $1 \mu \mathrm{D}$ to $6 \mathrm{D}$ permeability range at $2.5 \mathrm{~cm}$ plug diameter. Measuring time for medium to highly permeable samples is roughly 5 to $10 \mathrm{~min}$. This device can also be used to determine permeability for different fluids and automatically corrects for viscosity and temperature effects.

Main components of both devices are a downstream controller in front of the Hassler cell, gas-flow monitors of different ranges behind the Hassler cell, followed by an upstream controller to realize back pressure. Pressure gradient within the sample is metered by a differential pressure gauge directly at the upstream and downstream sample endings by additional non-percolated probes to avoid friction. These parameters are used as a direct input into the Darcy equation, together with temperature- and pressure-corrected air viscosities and volumes. 


\subsubsection{Probe permeameter gas-flow geometry in rock samples}

For all kinds of minipermeameter devices, the knowledge about gas-flow geometry is crucial in order to get area $(A)$ and length $(L)$ parameters as input for the Darcy equation (Eq. 1). However, quantifying these parameters represents a major problem as flow trajectories are not parallel, not equally spaced, and not of the same length (Fig. 2a). For absolutely homogenous and anisotropic samples, a so-called geometric factor $(L / A)$ can be modelled and calculated even for different sample geometries to replace the length $(L)$ and area $(A)$ parameters of the Darcy equation (Eq. 1). In geoscience practice, natural samples are investigated which can almost never be considered as isotropic, nor homogenous due to depositional and diagenetic effects. Therefore, a significantly better accuracy of the results can be achieved when a calculated geometric factor is replaced by an empirical factor, closely adapted to a certain rock type (Fig. 2b). Hence, we recommend measuring a set of samples with both devices: the Hassler cell permeameter and in the same direction (plug faces) with a minipermeameter. From this data set an empirical geometry factor can be determined by balancing averaged minipermeameter values of both plug faces with Hassler cell measures. This set of test samples should cover the whole range of permeabilities of a rock type. Rock types should be chosen so as to represent all types of potential controls affecting pore space geometry and sample architecture (e.g. lithology, detrital grain composition, degree and type of cementation, and sedimentary fabrics). To keep it simple even for non-geologists, such a suite of rock types could be for example limestone with different visible sedimentary structures, homogenous limestone, and groups of diagenetically overprinted limestone showing leaching, microkarst, fracturing, or patchy cementations. Similarly, such test sets should be established for sandstones.

To be close to the common practice as recommended above, in this study the geometric factor for the MDA was not established at the used 51 samples. On purpose, a comparable, previous test set for moderately permeable, homogenous sandstones was used, and an overall geometric factor for the MDA was determined $\left(0.15 \mathrm{~m}^{-1}\right)$. Using the same 51 samples as a test set, the results would show much better matching, which is not realistic for common practice. As the geometric factor $(A / L)$ represents a linear relationship in the Darcy equation (see Eq. 1), an error in determination will affect the matching of minipermeameters to Hassler cells in the same range.

\subsubsection{Mini permeameters}

The minipermeameters (or probe permeameters) have been applied attached to the end faces of the core plug samples, providing bedding-parallel permeability data of the core plug long-axis directions. These measurements can then be di- a) Homogeneous core plug

b) Heterogeneous core plug

(e.g. trough cross bedded)

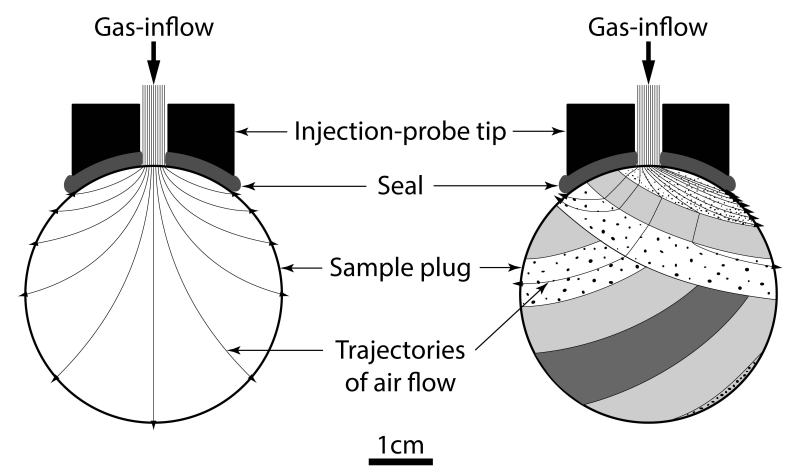

Permeability:

$\therefore$ very high $\quad \square$ high low

Fig. 2. Gas-flow trajectories for (a) homogeneous samples and (b) for heterogeneous samples (e.g. comprising depositional or diagenetic anisotropies). Such structures strongly affect flow geometry by inducing preferential flow, which creates serious issues in determining flow length and area for permeability measurements.

rectly compared to Hassler-cell-derived permeability measurements. Minipermeameter measurements are governed by seal tightness which is strongly influenced by seal surface pressure, the angle of the probe tip with the sample surface and the roughness of the sample surface. Potential leakage has a large influence on the measuring results. The seal tightness of these devices is achieved by a tight contact between nozzle, sealing rubber, and sample surface, and can be further improved by a ring of putty. For a better comparison of applied probe tip seals, Goggin et al. (1988) use the dimensionless probe-tip seal size defined as $b_{\mathrm{D}}=($ external seal radius) / (internal seal radius). A minimum size of $b_{\mathrm{D}}=1.5$ is recommended by Suboor and Heller (1995), whilst Meyer and Krause (2001) apply a $b_{\mathrm{D}}$ of 2.19 .

\section{Minipermeameter Darmstadt}

The Darmstadt permeameter can be operated also in a minipermeameter mode (Minperm Darmstadt $=$ MDA), using air injection (Fig. 1b). The MDA is mounted on a static rack with automatic seal pressure control to ensure constant tightness conditions. It injects at a diameter of $4 \mathrm{~mm}$ and seals an area of $25 \mathrm{~mm}$ of diameter $\left(b_{\mathrm{D}}=6.25\right)$. Different sealing tips are used to adjust for curvatures of samples. Plugs of all diameters, any plane surface or irregularly shaped samples can be handled. It delivers a threedimensional apparent permeability, which can be used to quantify anisotropy at small scale. By applying geometric factors, the apparent permeability of the miniperm mode is adjusted to results of the HDA Hassler-cell mode by experiments as described in Sect. 2.2.2. The measurable 
permeability range is almost identical to that of the HDA device. A single measurement takes roughly $30 \mathrm{~s}$ for medium to highly permeable samples, and for a complete 3-D survey 12 single measurements are recommended.

The same sensors as in Hassler-cell operation mode are used, but as it releases gas into the atmosphere, no back pressure can be applied and all parameters have to be measured in the upstream branch of the device. Parameter corrections are applied identically to the Hassler-cell operation mode. To test leakages of the tip seal or in the device, samples which are considered to have no permeability are measured. In this case, an alloy plug in the same dimensions as a core plug was used. The results were below the sensitivity of the sensors, so we assume a complete technical tightness. We recommend such a test for any other device.

\section{TinyPerm II probe permeameter}

The minipermeameter "TinyPerm II" (Miniperm Tiny Perm $=$ MTP) of New England Research Inc. was applied at the GeoZentrum Nordbayern, University of ErlangenNürnberg. It is a portable handheld air permeameter (Fig. 1c) which can be used in the laboratory or in the field directly on the surface of sample plugs, well cores, hand specimens, and plane, cleaned outcrop walls. The MTP probe tip consists of a $22 \mathrm{~mm}$-sized rubber nozzle with an inlet diameter of $9 \mathrm{~mm}$. To prevent leakage between probe tip and sample surface, the nozzle was additionally equipped with an impermeable expanded rubber ring of $9 \mathrm{~mm}$ inner diameter (inlet) and $27 \mathrm{~mm}$ outer diameter, providing a $9 \mathrm{~mm}$-thick seal around the inlet. The application of this additional seal is highly recommended to optimize MTP measurements. As the expanded rubber is very flexible, it tightens the surface roughness of the sample, which prevents leaking and forces the air to trespass only the rock sample. Here, the probe-tip seal size $b_{\mathrm{D}}$ according to Goggin et al. (1988) is $b_{\mathrm{D}}=3.0$. To provide reproducible testing conditions and a uniform contact pressure during operation, the MTP device was mounted in an upright static position. The probe nozzle is pressed against the rock sample, and subsequently a vacuum is generated in the inner part of the instrument. According to the manufacturer (New England Research Inc.), a microcontroller monitors the volume of withdrawn air from the rock and the transient vacuum. After the vacuum is dissipated, the microcontroller computes a characteristic value according to the measured parameters. This TinyPerm II value $(T)$ is provided after the measurement of one sample and is linked to air permeability $(K)$ through Eq. (2) (according to the TinyPerm II operational manual):

$T=-0.8206 \log _{10}(K)+12.8737$,

where $K$ is the permeability in millidarcys ( $\mathrm{mD}$ ).

This equation needs to be applied to all values provided by the MTP device after the measurement of one sample, to calculate the correct permeability in millidarcys. Empirical

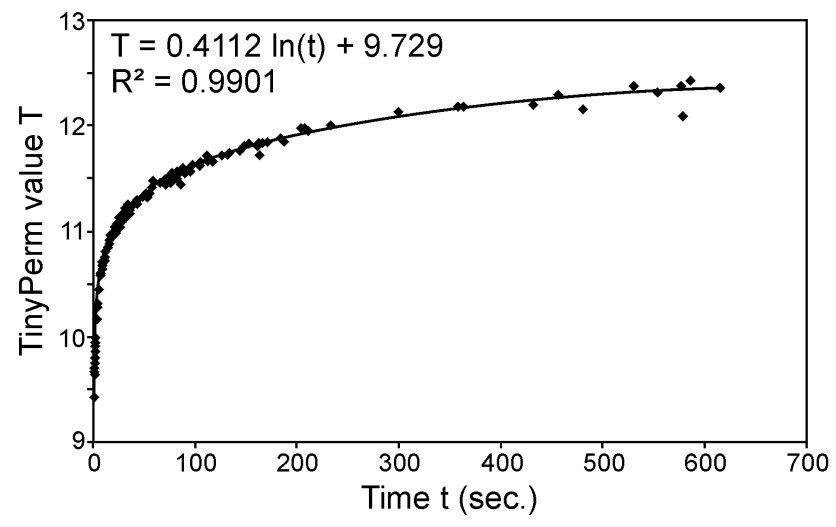

Fig. 3. Cross-plot of TinyPerm II value $(T)$ with needed measuring time $(t)$ in seconds. Note the asymptotic behaviour of the regression line with increasing measuring time.

experiments show that the value $T$ also correlates with measuring time (Fig. 3).

The technical tightness of the MTP device was then tested with a perfectly flat and polished solid aluminium block, simulating a non-permeable sample. In the ideal case, the vacuum should not dissipate when impermeable materials are measured. Over a measuring period of $4 \mathrm{~h}$, the device indicates a slow decay of the vacuum. The extrapolation of this decay delivers a time span of $10 \mathrm{~h}$ and $9 \mathrm{~min}$ for the entire dissipation of the vacuum. Applying the correlation of measuring time versus TinyPerm value (Fig. 3), a measuring time of $10 \mathrm{~h}$ and $9 \mathrm{~min}$ provides $T=14.08$, which equals an apparent permeability of the solid aluminium block of $0.034 \mathrm{mD}$ (calculated using Eq. 2). This technical tightness defines the lower measuring boundary of the TinyPerm II, limited to $0.034 \mathrm{mD}$. Since the TinyPerm II device was originally designed for a handheld field application, the manufacturer indicates a lower measuring boundary of approximately $10 \mathrm{mD}$, which is equivalent to a measuring time of about $5 \mathrm{~min}$ (Fig. 3). Longer measuring times and thereby lower permeabilities may only be realized in the laboratory where the device can be mounted on a static rack.

The application of different sample sizes additionally influences minipermeameter measuring results. Flow paths in sample plugs as illustrated in Figs. 1 and 2 may differ from those in unconfined samples, such as outcrop walls. The TinyPerm II is the only tested instrument which was originally designed for field application, used in several field studies before (e.g. Torabi and Fossen, 2009; Huysmans et al., 2008). To detect potential discrepancies between TinyPerm outcrop and plug sample measurements, unconfined outcrop measurements were simulated on four $10 \mathrm{~cm} \times 10 \mathrm{~cm} \times 10 \mathrm{~cm}$ rock blocks, representing permeability orders of $10^{0}, 10^{1}, 10^{2}$, and $10^{3} \mathrm{mD}$. A 1-inch sample plug was then drilled from the measuring point on the block and measured again. As a result, TinyPerm measurements are $34-41 \%$ lower on unconfined samples than on plug samples, 
Table 2. Comparison of TinyPerm measurements (MTP) from four "unconfined" rock blocks $(10 \times 10 \times 10 \mathrm{~cm})$ and the corresponding 1-inch sample plugs, representing permeability orders of $10^{0}, 10^{1}$, $10^{2}$, and $10^{3} \mathrm{mD}$. Measured permeabilities are $34-41 \%$ lower on unconfined samples than on plug samples (mean: $-36.9 \%$ ).

\begin{tabular}{llll}
\hline & $\begin{array}{l}\text { Block } \\
\text { (MTP) }\end{array}$ & $\begin{array}{l}\text { Plug } \\
\text { (MTP) }\end{array}$ & $\begin{array}{l}\text { Block } \\
\text { vs. plug }\end{array}$ \\
\hline Buntsandstein & 4.6 & 7.2 & $-36 \%$ \\
Buntsandstein & 803.2 & 1369 & $-41 \%$ \\
Keuper & 60.8 & 92.6 & $-34 \%$ \\
Bentheim sandstone. & 1285 & 1999 & $-36 \%$ \\
& & Mean & $-36.9 \%$ \\
\hline
\end{tabular}

with an average of $\sim 37 \%$ (Table 2). The effect of shorter flow trajectories and apparent higher permeabilities in plug samples can be corrected by reducing MTP plug measurements by $37 \%$. We use this corrected TinyPerm permeability (MTP-c) to compare TinyPerm plug sample with Hassler cell measurements properly.

\section{Comparison of Hassler cell and minipermeameter measurements}

When permeability measurements from different Hassler cells, different minipermeameters or a mixture of Hassler cell and minipermeameter measurements are integrated in one study, system-immanent discrepancies between the applied devices should be taken into account and, where necessary, should be corrected. Therefore, transform equations for the used devices need to be determined and applied for comparison. All permeability measurements conducted with the four devices used in this study are listed in Table 1 and plotted in Fig. 4. The results are then cross-plotted to visualize the correlation of the different permeability devices and, if necessary, to receive transform equations for correction and standardization (Figs. 5 and 6).

\subsection{General trends of measuring results}

The permeabilities of all 51 core plug samples have been measured with each of the four permeameter devices and are plotted in Fig. 4 for comparison. General permeability trends and magnitudes, and the aberrations of the respective permeability devices are discussed. The most eyecatching aberrations are shown by uncorrected TinyPerm II measurements (MTP), which in the majority of cases determine higher permeabilities than all other devices. Markedly higher values are recorded in $47 \%$ (24 samples), similar values in $37 \%$ (19 samples), and slightly lower values in $18 \%$ (9 samples) of the cases. TinyPerm measurements have then been corrected for unconfined rock volumes as discussed in Sect. 2.2.3 and presented in Tables 1 and 2. The Hassler cell in Darmstadt (HDA) shows pronounced lower permeabilities

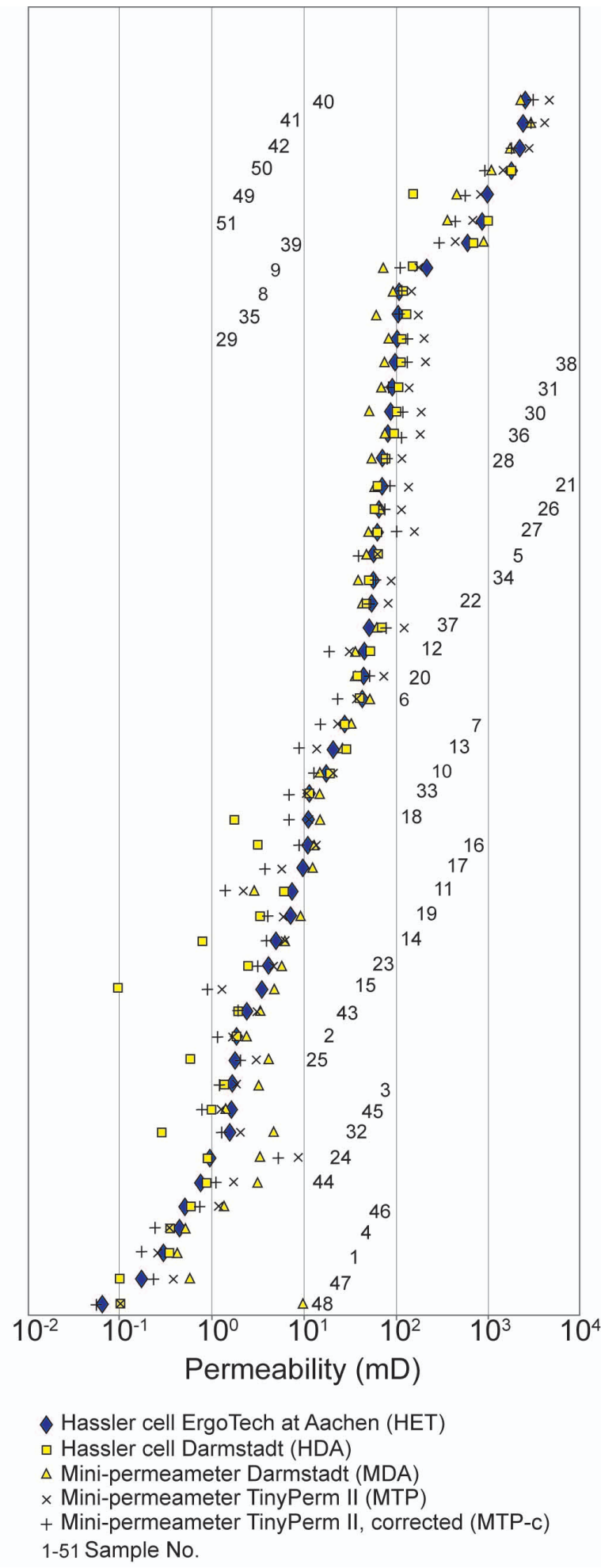

Fig. 4. Permeability data derived from 51 core plug samples, measured with four different air permeameters: the Hassler cells of the ErgoTech gas permeameter (HET, blue diamonds) and the gas permeameter in Darmstadt (HDA, yellow squares), and the minipermeameters Miniperm Darmstadt (MDA, yellow triangles) and TinyPerm II (MTP, crosses). 

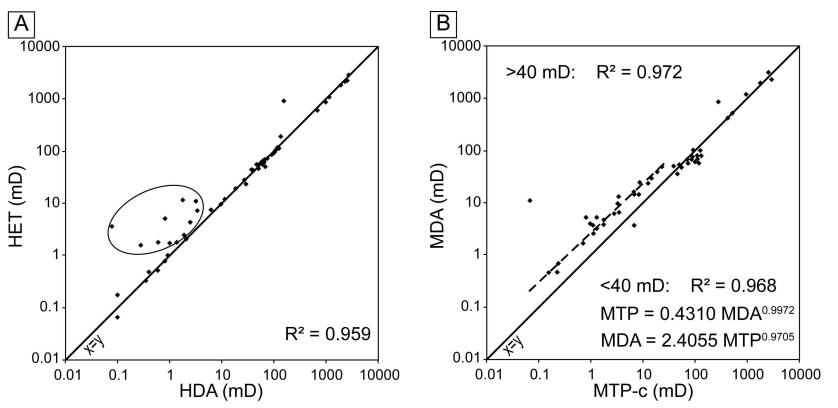

Fig. 5. Comparison of different gas permeameters: (A) the Hassler cell devices ErgoTech gas permeameter (HET) versus the gas permeameter in Darmstadt (HDA), and (B) the minipermeameters Miniperm Darmstadt (MDA) versus TinyPerm II (MTP). The MTP values are corrected by $-37 \%$ (MTP-c) to compensate for reduced flow trajectories. The bisectrix $(x=y)$ indicates positive or negative aberrations of the measuring results, and the dashed line indicates the regression line of the resulting transform equations for standardization. Note the bi-logarithmic scales.

mostly limited to permeabilities of $<10 \mathrm{mD}$. Obviously most aberrations, positive and negative, range on the same order of magnitude like the respective measuring results of the other devices.

\subsection{Individual comparison of permeability devices}

The combination of permeability values obtained from different approaches requires a profound understanding of potential discrepancies between the applied devices. The individual measurement results of all four permeameters are cross-plotted against each other (Figs. 5 and 6) to obtain particular information on their systematic similarities and discrepancies.

\subsubsection{Hassler cell measurements: HET versus HDA}

The Hassler cells (HET and HDA) generate well-correlated measuring results, with a coefficient of determination of $R^{2}=0.959$ (Fig. 5a). Most of the presented Hassler cell measurements are almost identical or very close to each other (36 samples $=71 \%$ ), plotting near the bisectrix (solid line). In most cases, a one-to-one correlation between the two Hassler cells applies very well. However, major deviations have been observed in the measuring interval between 1 and $10 \mathrm{mD}$. Here, the HDA shows markedly lower values than the HET. The permeability values of seven samples deviate as much as one order of magnitude. Minor aberrations are within the same order of magnitude.

\subsubsection{Minipermeameters: MDA versus MTP-c}

The MDA vs. MTP-c cross-plot (Fig. 5b) indicates major aberrations of the two minipermeameter devices from each other. In the lower permeability range $(<40 \mathrm{mD})$, a promi-
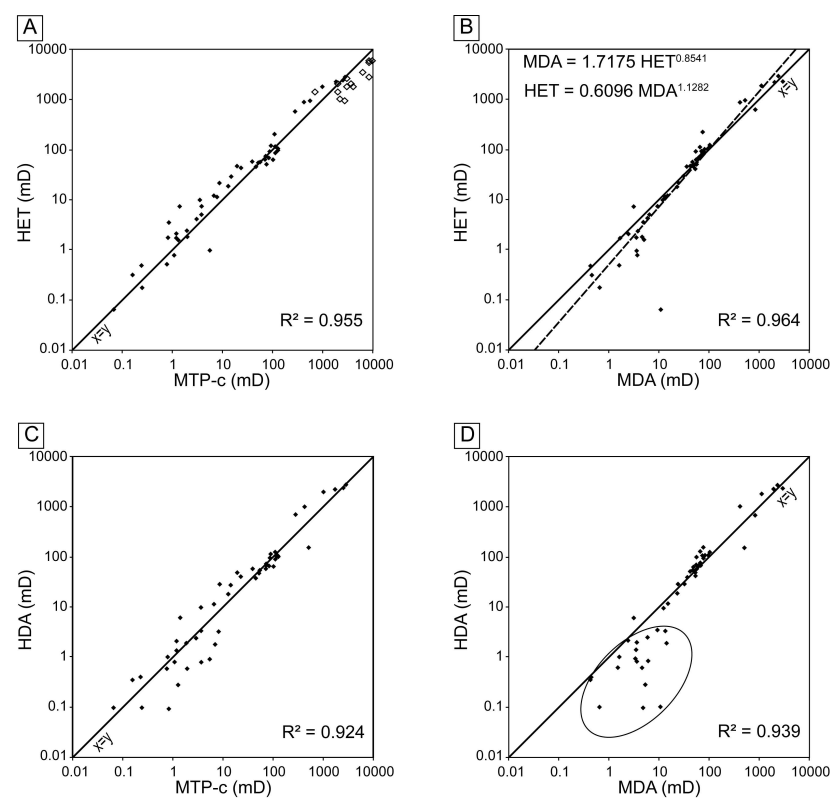

Fig. 6. Comparison of Hassler cell versus minipermeameter measurements: ErgoTech gas permeameter (HET) versus TinyPerm II (MTP) (A) and Miniperm Darmstadt (MDA) (B), and the gas permeameter in Darmstadt (HDA) versus TinyPerm II (MTP) (C) and Miniperm Darmstadt (MDA) (D). The MTP values are corrected by $-37 \%$ (MTP-c) to compensate for reduced flow trajectories. The bisectrix $(x=y)$ indicates positive or negative aberrations of the measuring results, and the dashed line indicates the regression line of the resulting transform equations for standardization. Note the bi-logarithmic scales. Outcrop and Hassler cell data from Fossen et al. (2011) are additionally shown in (A) (open diamonds, unmodified MTP values).

nent offset identifies systematically higher MDA values, approximately 2.4 times higher than TinyPerm measurements. However, at permeability values $>40 \mathrm{mD}$, MTP-c and MDA values are almost identical. A partial regression line can be drawn separately for the lower section $(<40 \mathrm{mD})$ to correct MDA for MTP-c values, and vice versa. In both cases, the coefficient of determination $R^{2}$ of MDA versus MTP is very good, with 0.968 for the permeability range $<40 \mathrm{mD}$ and 0.972 for $>40 \mathrm{mD}$.

\subsubsection{Hassler cell versus minipermeameter measurements}

Figure 6 compares Hassler cell measurements of the ErgoTech (HET) and the Darmstadt (HDA) devices with minipermeameter measurements of the TinyPerm II (MTPc) and the Darmstadt device (MDA). Both minipermeameters show high coefficients of determination $\left(R^{2}\right)$ with the Hassler cells of the HET device $\left(R^{2}=0.955\right.$ and 0.964 ; see Fig. 6a and b) and the HDA device $\left(R^{2}=0.924\right.$ and 0.939 ; see Fig. 6c and d). The corrected permeability measurements of the MTP (MTP-c) and the HET plot very close 
to the bisectrix (Fig. 6a, solid diamonds), showing a close match of these two permeameters. However, between 1 and $40 \mathrm{mD}$, rock-volume-corrected MTP measurements tend to be slightly lower than HET data. TinyPerm outcrop and Hassler cell data with permeabilities $>1 \mathrm{D}$ from Fossen et al. (2011) are plotted for comparison (Fig. 6a, open diamonds).

The MDA minipermeameter and the HET Hassler cell exhibit some minor aberrations (Fig. 6b). There, the best-fit line is rotated anticlockwise compared to the bisectrix. Below $\sim 40 \mathrm{mD}$, the MDA indicates higher permeabilities than the HET device. At $\sim 40 \mathrm{mD}$ however, a turn-around point occurs, above which the MDA tends to deliver mostly lower permeability values than the HET.

Cross-plots of the Darmstadt Hassler cell (HDA) with the two minipermeameters indicate high correlation at permeability magnitudes $>10^{1} \mathrm{mD}\left(R^{2}=0.924\right.$ and 0.939$)$, but they show deviations at the permeability range $<10 \mathrm{mD}$ (Fig. 6c and d). These aberrations are only minor in the HDA vs. MTP-c cross-plot (Fig. 6c) and are much more pronounced in the HDA-MDA cross-plot (Fig. 6d). However, this pronounced deviation may be the combined effect of a slight underestimation of permeability by the HDA device and an overestimation by the MDA minipermeameter at the same time (as documented in Fig. 6b).

\subsection{Discussion of measuring results}

To enhance accuracy of different gas-driven permeability measurements, device-specific aberrations have been documented from Hassler cell and minipermeameter measurements. Permeability over- and underestimations either by minipermeameters or Hassler cells may result from variable factors.

Sealing quality and surface roughness play an important role in leak tightness of minipermeameters. Here, permeability overestimations of minipermeameter devices (Figs. 4 and 6a-d) may be attributed to suboptimal probe tip sealing, especially when sample surfaces are very rough (e.g. coarsegrained sandstones or irregular (non-sawed) surfaces). Due to shorter flow trajectories and a reduced rock volume, the TinyPerm II device largely overestimates plug sample permeabilities. Therefore it is proposed correcting them for unconfined rock volumes.

Permeability underestimations, however, require other explanations. Covering only a very limited surface, minipermeameter measurements are susceptible to even small-scale rock heterogeneities. For instance, individual, stronger cemented parts may deliver lower permeabilities in punctual minipermeameter measurements. On the other hand, preferential flow in Hassler-cell devices mainly contributes to the overall permeability of the sample, whereas punctual preferential flow in minipermeametry just contributes as only one higher value among many lower (= "normal") ones; therefore the preferential flow is underrated when multiple mea- surements are used to average a sample (e.g. MTP, MDA). A technical explanation for underestimation of minipermeameter versus Hassler recordings could be that a strong contact pressure of the minipermeameter probe may slightly force the sealing rubber towards the inner part of the probe tip. This would also narrow the inflow/outflow tube diameter to a certain degree. The effect of a reduced in- or outflow diameter then results in an apparent lower permeability. These two reasons may explain the documented underestimations of minipermeameter measurements compared to the Hassler cell devices.

Hassler cell measurements provide a permeability value which is integrated over a given rock volume. Individual and spatially limited sections of enhanced cementation within this rock volume affect bulk permeability only little, whereas they have a much more pronounced effect on point measurements (Fig. 2b). Cross-plots further indicate that the HDA Hassler cell tends to provide slightly lower permeability at a permeability range of $<10 \mathrm{mD}$ compared to the other devices (Figs. 5a, 6c, 6d). This is due to the technical specifications of all kinds of ultra-low range gas-flow meters. In general they show a much higher pressure drop compared to mid- or high range sensors, which changes flow conditions in the sample.

For better comparison and for merging permeability data sets which have been generated with different devices, permeability measurements need to be standardized for one permeameter type. The presented cross-plots show that permeability measurements from different devices correlate very well, with coefficients of determination $\left(R^{2}\right)$ between 0.924 and 0.972 . Frequently, they are in good accordance with the bisectrix, indicating that the plotted data sets can roughly be correlated one to one. However, the good correlation is not equally distributed across the entire range of permeabilities. These aberrations need to be considered when data sets generated by variable measurement devices shall be merged.

One-to-one correlations can generally be applied for rockvolume-corrected TinyPerm II (MTP-c) and ErgoTech Hassler cell (HET) measurements (see Fig. 6a). However, MTP-c values seem to be systematically lower between 1 and $40 \mathrm{mD}$. The additionally plotted data points of Fossen et al. (2011) indicate significantly higher TinyPerm values at the permeability range $>1 \mathrm{D}$. The explanation might be the effect of differently applied sealing rubber sizes, a lower contact pressure during outcrop measurement, or the higher surface roughness of natural outcrops compared to sawed rock samples.

One-to-one correlations can be used only to a limited extend when the HDA Hassler cell is combined with any other of the devices considered in this study. Restrictions occur in the permeability interval of $1-10 \mathrm{mD}$, when using the HDA and HET Hassler cells (Fig. 5a), and at permeabilities $<10 \mathrm{mD}$, when the HDA is combined with the minipermeameter MDA (Fig. 6d). As discussed above, the HDA Hassler cell constantly provides lower permeabilities in this range. 
The standardization of MDA minipermeameter and HET Hassler cell measurements requires a correction across the entire range of permeabilities, applying the respective transform equations outlined in Fig. 6b. The standardization of MDA measurements for HET permeability follows the transform equation $\mathrm{HET}=0.6096 \mathrm{MDA}^{1.1282}$, where "MDA" describes the permeability measured with the MDA device. As a result, the corresponding HET permeability is obtained. Due to the rotation of the best-fit line (Fig. 6b), this transform becomes more effective in very low permeability classes $<1 \mathrm{mD}$ or at high permeabilities $>1000 \mathrm{mD}$, and can be largely neglected at a range of $10-100 \mathrm{mD}$.

In studies where the two minipermeameters MTP and MDA are applied, minor corrections are necessary to standardize for one device. The cross-plot (Fig. 5b) illustrates a very good correlation, but at permeabilities $<40 \mathrm{mD}$ the MTP versus MDA permeability measurements are displaced parallel to the bisectrix towards higher MDA values. Therefore, two different transforms need to be applied for standardization of MTP or MDA measurements (Fig. 5b).

All presented cross-plots demonstrate that it is of crucial importance to document major aberrations prior to the use of different permeameters within one study. A general rule for how a specific device will compare to others cannot be established and has to be defined by empirical measurements.

The technique to establish empirical equations to make permeability comparable among different devices can also be used to compare gas permeability to water-derived permeabilities. Examples are given in Jaritz (1999) and Al Ajmi et al. (2013). As a common result intrinsic gas permeabilities are found to be $50 \%$ higher than water permeabilities. As an explanation gas-slippage effects at the rock interface were made responsible.

\section{Conclusions}

Permeability data of reservoir rocks mainly derive from core plug measurements using Hassler cell devices. On the other hand, probe permeameters have the advantage of providing closely spaced, non-destructive permeability data, which are mostly suitable to gain 3-D permeability, estimates of anisotropy effects, and heterogeneity.

In studies where both techniques are applied, it is of paramount importance to guarantee comparability of the obtained data sets. This is particularly important if permeameters designed for outcrop application, like the TinyPerm II device, shall be used for laboratory plug measurements. In this case, unconfined samples show on average $37 \%$ lower permeabilities than plug samples.

Permeability measurements derived from four different Hassler cell and minipermeameter devices have been compared to document their correlation. As a result of permeability cross-plots, device-typical aberrations and transform equations are elaborated, which enable corrections for spe- cific Hassler cell or probe permeameter data. The application of simple one-to-one correlations is highly critical, as aberrations and trends may occur across the entire range of permeabilities or may only be confined to certain permeability intervals.

Only in some cases, one-to-one correlations between different permeameters can be applied to the entire range of permeability. Here, the Hassler cell of the ErgoTech gas permeameter (HET) and the rock-volume-corrected values of the TinyPerm II minipermeameter (MTP-c) show the closest match $\left(R^{2}=0.955\right)$. The combination and standardization of permeability data derived from other devices, however, requires various corrections.

With this study we demonstrate that variable devicespecific aberrations exist between different permeameter types, and we show a methodology to integrate minipermeameter data better with the commonly more widely spaced and more interpolative core plug permeability derived from Hassler cell measurements. Hence, it is possible to benefit from the advantages of both concepts.

Acknowledgements. Peter Kukla is highly appreciated for providing access to the ErgoTech gas permeameter of the Geological Institute of RWTH Aachen University, Germany. We are grateful for the constructive comments of $\mathrm{H}$. Fossen and a second, anonymous reviewer, which substantially improved an earlier version of this manuscript.

Edited by: P. Papale

\section{References}

Al Ajmi, H., Hinderer, M., Hornung, J., Bassis, A., Keller, M., Rausch, R., and Schüth, C.: Matrix versus fracture permeability in a regional sandstone aquifer (Wajid sandstone, SW Saudi Arabia), Grundwasser, in press, 2013.

Branets, L. V., Ghai, S. S., Lyons, S. L., and Wu, X.-H.: Challenges and technologies in reservoir modeling, Commun. Comput. Phys., 6, 1-23, 2009.

Chandler, M. A., Goggin, D. J., and Lake, L. W.: A mechanical field permeameter for making rapid, non-destructive, permeability measurements, J. Sediment. Petrol., 59, 613-615, 1989.

Corbett, P. W. M. and Jensen, J. L.: Variation of reservoir statistics according to sample spacing and measurement type for some intervals in the lower Brent Group, Log Analyst, 33, 22-41, 1992.

Darcy, H.: Les fontaines publiques de la ville Dijon, Dalmont, Paris, 674 pp., 1856.

Davies, J. P. and Davies, D. K.: Stress-dependent permeability: characterization and modeling, SPE J., 6, 224-235, 2001.

Davis, J. M., Wilson, J. L., and Phillips, F. M.: A portable airminipermeameter for rapid in situ field measurements, Ground Water, 32, 258-266, 1994.

Dezayes, C., Thinon, I., Courrioux, G., Tourlière, B., and Genter, A.: Estimation du potentiel géothermique des réservoirs clastiques du Trias dans le Fossé rhénan, Final report, BRGM/RP55727-FR, 72, 2007. 
Dreyer, T., Scheie, A., and Jensen, J. L.: Minipermeameter-based study of permeability trends in channel sand bodies, AAPG Bullet., 74, 359-374, 1990.

Dutton, S. P. and Willis, B. J.: Comparison of outcrop and subsurface sandstone permeability distribution, Lower Creataceous Fall River Formation, South Dakota and Wyoming, J. Sediment. Res., 68, 890-900, 1998.

Dutton, S. P., Laubach, S. E., and Tye, R. S.: Depositional, diagenetic, and structural controls on reservoir properties of lowpermeability sandstone, Travis Peak Formation, East Texas, Gulf Coast Assoc. Geol. Soc. T., 41, 209-220, 1991.

Eijpe, R. and Weber, K. J.: Mini-permeameters for consolidated rock and unconsolidated sand, AAPG Bullet., 55, 307-309, 1971.

Fossen, H., Schultz, R. A., and Torabi, A.: Conditions and implications for compaction band formation in the Navajo Sandstone, Utah, J. Structur. Geol., 33, 1477-1490, 2011.

Goggin, D. J.: Geologically sensible modeling of the spatial distribution of permeability in eolian deposits: Page Sandstone (Jurassic), northern Arizona, PhD, The University of Texas at Austin, 417 pp., 1988.

Goggin, D. J.: Probe permeametry: is it worth the effort?, Mar. Petrol. Geol., 10, 299-308, 1993.

Goggin, D. J., Thrasher, R. L., and Lake, L. W.: A theoretical and experimental analysis of minipermeameter response including gas slippage and high velocity flow effects, In Situ, 12, 79-116, 1988.

Grant, M. A. and Bixley, P. F.: Geothermal reservoir engineering, 2nd Edn., Academic Press Elsevier Burlington, USA, 2011.

Halvorsen, C. and Hurst, A.: Principles, practice, and applications of laboratory minipermeametry, in: Advances in core evaluation: accuracy and precision in reserves estimation, edited by: Worthington, P. F., Gordon and Breach, London, 521-549, 1990.

Hornung, J. and Aigner, T.: Reservoir architecture in a terminal alluvial plain: an outcrop analogue study (Upper Triassic, Southern Germany). Part 1: Sedimentology and petrophysics, J. Petrol. Geol., 2, 3-30, 2002.

Hurst, A.: Sedimentary flow units in hydrocarbon reservoirs: some shortcomings and a case for high-resolution permeability data, in: The geological modelling of hydrocarbon reservoirs and outcrop analogues, edited by: Flint, S. S. and Bryant, I. D., Special Publications International Association of Sedimentologists, Blackwell Scientific Publications, 191-204, 1993.

Hurst, A. and Goggin, D. J.: Probe permeametry: An overview and bibliography, AAPG Bullet., 79, 463-473, 1995.

Huysmans, M., Peetersa, L., Moermansa, G., and Dassarguesa, A.: Relating small-scale sedimentary structures and permeability in a cross-bedded aquifer, J. Hydrol., 361, 41-51, 2008.

Iversen, B. V., Moldrup, P., Schjonning, P., and Jacobsen, O. H.: Field application of a portable air permeameter to characterize spatial variability in air and water permeability, Vadose Zone J., 2, 618-626, 2003.

Jaritz, R.: Quantifizierung der Heterogenität einer Sandsteinmatrix (Mittlerer Keuper, Württemberg), Tübinger Geowissenschaftliche Arbeiten (TGA), C48, 1-106, 1999.
Kellogg, K., Janjou, D., Minoux, L., and Fourniguet, J.: Explanatory Notes to the Geologic Map of the Wadi Tathlith Quadrangle, Sheet 20 G, Kingdom of Saudi Arabia, Ministry of Petroleum and Mineral Ressources, Deputy Ministry of Mineral Resources, 27 pp., 1986.

Klinkenberg, L. J.: The permeability of porous media to liquids and gases, in: API Drilling and Production Practice, American Petroleum Institute, New York, 200-213, 1941.

Laughlin, A. W.: Exploration for geothermal energy, in: Handbook of geothermal energy, edited by: Edwards, L. M., Chilingar, G. V., Rieke, H. H., and Fertl, W. H., Gulf Publishing company, Houston, 1982.

Li, D., Cullick, A. S., and Lake, L. W.: Global scale-up of reservoir model permeability with local grid refinement, J. Petrol. Sci. Eng., 14, 1-13, 1995.

Meyer, R. and Krause, F. F.: A comparison of plug-derived and probe-derived permeability in cross-bedded sandstones of the Virgelle Member, Alberta, Canada: The influence of flow directions on probe permeametry, AAPG Bullet., 85, 477-489, 2001.

Robertson, G. M. and McPhee, C. A.: High-resolution probe permeability: an aid to reservoir description, in: Advances in core evaluation, volume 1: accuracy and precision in reserves estimation, edited by: Worthington, P. F., Gordon and Breach, London, 495-520, 1990.

Rogiers, B., Beerten, K., Smeekens, T., and Mallants, D.: Air permeability measurements on Neogene and Quaternary sediments from the Campine area: using outcrop analogues for determining hydrodynamic aquifer properties, Belgian Nuclear Research Center, Mol, BelgiumExternal Report SCKCEN-ER-177, 2011.

Roll, A.: Bramberge Field, Federal Republik of Germany: Case Histories, in: Stratigraphic oil and gas fields - Classification, Exploration Methods, and Case Histories, AAPG Special Volumes, 286-296, 1972.

Sharp Jr., J. M., Fu, L., Cortez, P., and Wheeler, E.: An electronic minipermeameter for use in the field and laboratory, Ground Water, 32, 41-46, 1994.

Suboor, M. A. and Heller, J. P.: Minipermeameter characteristics critical to its use, In Situ, 19, 225-248, 1995.

Sutherland, W. J., Halvorsen, C., Hurst, A., McPhee, C. A., Robertson, G., Whattler, P. R., and Worthington, P. F.: Recommended practice for probe permeametry, Mar. Petrol. Geol., 10, 309-317, 1993.

Thomas, R. D.: Effect of overburden pressure and water saturation on gas permeability of tight sandstone cores, J. Petrol. Technol., 24, 120-124, 1972.

Todd, D. K. and Mays, L. W.: Groundwater Hydrology, 3rd Edn., Wiley, Hoboken, USA, 636 pp., 2005.

Torabi, A. and Fossen, H.: Spatial variation of microstructure and petrophysical properties along deformation bands in reservoir sandstones, AAPG Bullet., 93, 919-938, 2009.

Willis, B. J.: Permeability structure of a compound valley fill in the Cretaceous Fall River Formation of South Dakota, AAPG Bullet., 82, 206-227, 1998. 